\title{
Temporal variability of groundwater seepage and brown tide blooms in a Long Island embayment
}

\author{
Christopher J. Gobler*, Sergio A. Sañudo-Wilhelmy
}

Marine Sciences Research Center, State University of New York at Stony Brook, Stony Brook, New York 11794-5000, USA

\begin{abstract}
Blooms of Aureococcus anophagefferens, the alga responsible for brown tide in Long Island waters, have been hypothesized to occur during years in which groundwater discharge is low. The precise mechanism by which blooms are initiated, however, remains unknown. To better understand the influence of groundwater inputs on brown tide, a 2 yr sampling campaign was established at 'bloom-prone' embayment, West Neck Bay (WNB), Long Island, New York. During 1997 and 1998, changes in water-column chemistry and phytoplankton dynamics were observed, along with groundwater composition and flow rates. Groundwater entering WNB was enriched in nitrate $(>250 \mu \mathrm{M})$. During 1997 and 1998, elevated levels of dissolved nitrate (1 to $25 \mu \mathrm{M})$ were measured in the water column of WNB during the annual peak in groundwater flow. Peak nitrate levels were followed by mixed-assemblage phytoplankton blooms that were succeeded by monospecific brown tide with densities $>5 \times 10^{5} \mathrm{cells} \mathrm{m}^{-1}$. Interannual differences in groundwater seepage were reflected in the magnitude of water-column nitrate concentrations and phytoplankton biomass. Fifty percent more groundwater recharge in spring of 1998 compared to spring of 1997 resulted in levels of nitrate and

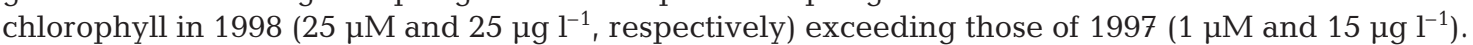
Phytoplankton blooms preceding brown tide may supply $A$. anophagefferens with organic nutrients, as annual bloom densities seemed dependent on the magnitude of dissolved organic nitrogen inputs prior to brown tide events. A multivariate regression model is presented which accounts for $72 \%$ of the variability in brown tide densities during the $2 \mathrm{yr}$ study period at WNB. A highly significant correlation between groundwater seepage and $A$. anophagefferens densities in the model suggests that rather than repressing brown tide, groundwater inputs to WNB can stimulate A. anophagefferens growth by initiating phytoplankton blooms prior to the brown tide which supply remineralized organic nitrogen.
\end{abstract}

KEY WORDS: Brown tide $\cdot$ Aureococcus anophagefferens $\cdot$ Groundwater $\cdot$ Harmful algal blooms Organic nitrogen $\cdot$ Nitrate

Resale or republication not permitted without written consent of the publisher

\section{INTRODUCTION}

Since 1985, brown tide blooms of the pelagophyte Aureococcus anophagefferens have plagued embayments across the Northeast United States, and have been most common to the bays of Long Island, New York. During bloom events, A. anophagefferens often

\footnotetext{
*Present address: Natural Science Division, Southampton College of Long Island University, Southampton, New York 11968, USA.

E-mail: cgobler@southampton.liu.edu
}

accounts for $>90 \%$ of algal biomass, and can exist at cell densities exceeding $10^{9}$ cells $\mathrm{l}^{-1}$, which creates a coffee-like coloration of bay waters (Cosper et al. 1989). Impacts of Long Island brown tide have included the decimation of commercially valuable bay scallop populations Argopecten irradians irradians and the elimination of eel grass beds Zostera marina (reviewed by Bricelj \& Lonsdale 1997).

The conditions responsible for brown tide events are not completely understood. Aureococcus anophagefferens has been shown to grow efficiently under the temperatures, salinities and light conditions found in Long Island bays (Cosper et al. 1989, LaRoche et al. 
1997, Milligan \& Cosper 1997). Long residence times of bay waters (Vieira 1989) and low grazing rates on $A$. anophagefferens (Lonsdale et al. 1996) permit the accumulation of rapidly dividing cells. Field and laboratory research suggests that $A$. anophagefferens may assimilate dissolved organic carbon (DOC) to supplement its cellular carbon requirements (Dzurica et al. 1989, Gobler \& Sañudo-Wilhelmy 2001), particularly under the low light conditions that persist during blooms (Milligan \& Cosper 1997). Unlike many coastal algal blooms, brown tides do not seem to be caused by nutrient loading, but instead are thought to form when inorganic nutrient levels are low (Cosper et al. 1989, Keller \& Rice 1989, LaRoche et al. 1997). Since A. anophagefferens grows efficiently on organic nitrogen sources in laboratory cultures (Dzurica et al. 1989) and seems to use various forms of organic nitrogen during bloom events (Berg et al. 1997, LaRoche et al. 1997), it has been proposed that brown tide occur in years of elevated dissolved organic nitrogen (DON) levels and reduced groundwater flow, which results in a low DIN supply (LaRoche et al. 1997, Schubert 1998).

Groundwater seepage influences the biogeochemistry of many shallow coastal environments. Seepage of groundwater nitrate is the principal $\mathrm{N}$ source for several estuaries (Johannes 1980, Valiela et al. 1992, Staver \& Brinsfield 1996) including the Peconic Estuary, where brown tide blooms are prevalent (LaRoche et al. 1997). While agriculture is a significant source of $\mathrm{N}$ to groundwater entering parts of the Peconics (LaRoche et al. 1997), urbanization of coastlines can also contribute to elevated $\mathrm{N}$ in groundwater (Persky 1986, Valiela et al. 1992). In coastal marine systems, where $\mathrm{N}$ frequently limits primary production (Nixon \& Pilson 1983), nutrient loading from groundwater seepage has been shown to greatly impact phytoplankton dynamics (Johannes 1980, Sewell 1982, Kinney \& Roman 1998) as well as entire ecosystems (Valiela et al. 1992, Short \& Burdick 1996).

To evaluate how groundwater inputs may influence brown tide, we established a 2 yr field campaign at a brown tide-prone embayment on Long Island, West Neck Bay (WNB). The goal of this study was to understand how changes in groundwater composition and flow rates may relate to water column chemistry and phytoplankton dynamics at WNB in 1997 and 1998. Organic (urea, DON, DOC) and inorganic (nitrate, ammonium, phosphate, silicate) nutrients potentially affecting phytoplankton growth were simultaneously measured in the water column of WNB and in groundwater surrounding the bay. To ascertain how groundwater inputs may be modified during seepage into WNB, groundwater samples were collected from both inland and intertidal sites. Finally, a multivariate regression model was created to determine which measured parameters were most valuable for the statistical description of brown tide densities in the field.

\section{METHODS}

Study area. West Neck Bay (WNB) is a small $\left(1 \mathrm{~km}^{2}\right)$, shallow (2 to $4 \mathrm{~m}$ ), enclosed embayment on Shelter Island, within the Peconic Estuary of eastern Long Island (Fig. 1). WNB has a long, winding, restricted channel that exchanges with the Peconic Estuary and gives the bay and its harbor a hydraulic residence time of approximately 12 d (DiLorenzo \& Ram 1991). The absence of tributaries and point-source anthropogenic inputs make this bay a relatively simple system, where chemical inputs can be largely attributed to groundwater seepage, diffusive benthic fluxes, and tidal exchange. Brown tide now are common to WNB (records dating back to 1987), with major blooms $\left(>5 \times 10^{5}\right.$ cells $\mathrm{ml}^{-1}$ ) occurring in 1987, 1990,1991, 1992, 1995, 1997 and 1998 (SCDHS 1987 to 1998). While the 1987, 1991 and 1995 WNB blooms coincided with brown tide throughout the Peconic Estuary, 1990, 1992, 1997, and 1998 were years in which blooms were unique to WNB (SCDHS 1987 to 1998).

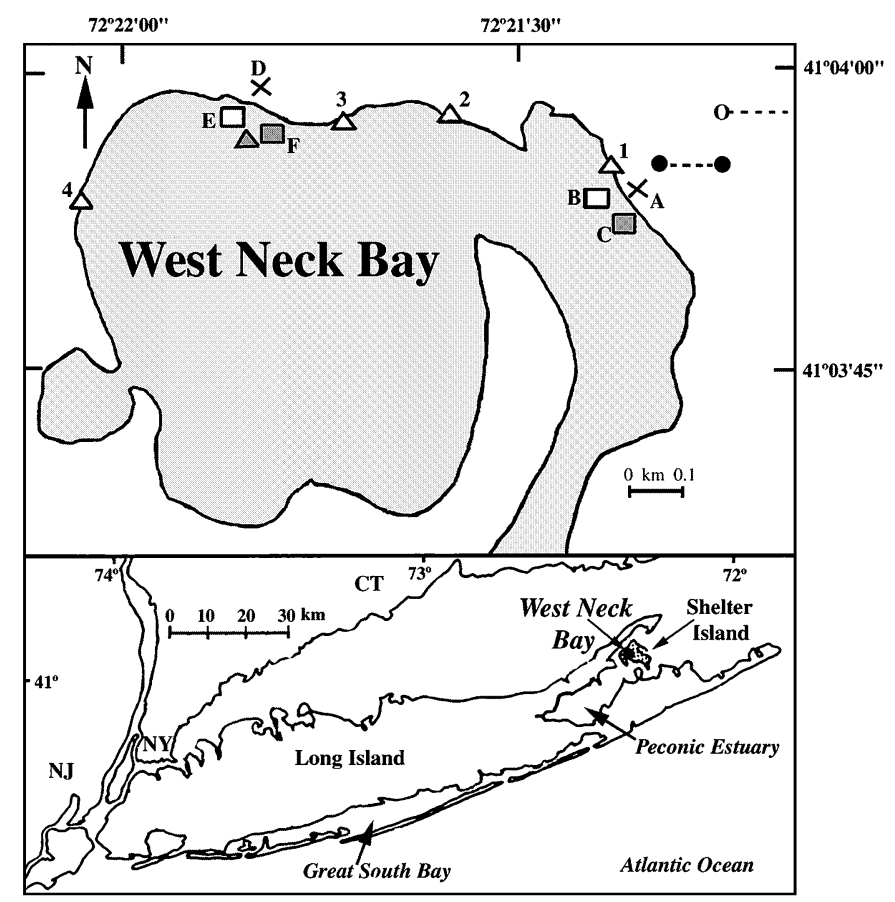

Fig. 1. West Neck Bay, Shelter Island, NY, showing locations of inland wells (X: Sites A and D), intertidal piezometers ( $\square$ Sites B and E), benthic seepage chambers ( $\square$ : Sites C and F), mean high water piezometers $(\Delta$ : Sites $1-4)$, bay sampling site

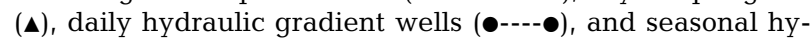
draulic gradient wells (o----). Second seasonal gradient well is not shown. See 'Methods' for description of sampling devices 
Sample collection. Groundwater in the aquifer surrounding WNB was sampled from 2 inland Teflonlined, PVC wells (Sites A \& D: Fig. 1) located 10 m beyond mean high water and $10 \mathrm{~m}$ deep. Groundwater entering WNB was sampled by 3 devices: (1) 3 m deep, Teflon-lined, PVC piezometers with $2.5 \mathrm{~cm}$ horizontal screened slits along the lower $25 \mathrm{~cm}$ located at mean high water mark (MHW) (Sites 1 to 4: Fig. 1); (2) shallow (1 m), Teflon-lined, PVC piezometers with slits as above, located within the intertidal zone (B and $E$ : Fig. 1); (3) benthic seepage chambers (vol. $=0.5 \mathrm{~m}^{3}$ ), located within the intertidal zone ( $\mathrm{C}$ and F: Fig. 1). Deployment of piezometers and seepage chambers at least $24 \mathrm{~h}$ before sampling allowed for equilibration with the benthic environment (Capone \& Bautista 1985). High groundwater seepage rates at WNB typically allowed intertidal samplers to fill with fresh groundwater (salinity <0.1 ppt) when sampled during low tide. Inland wells, intertidal piezometers, and benthic seepage chambers were sampled bi-weekly, from June through October 1998, whereas MHW piezometers were sampled once (1 September 1998) to define spatial variability of groundwater along the coastline of WNB (Fig. 1). Groundwater was sampled using a peristaltic pump equipped with acid-washed Teflon tubing. To ensure that representative groundwater was sampled, wells

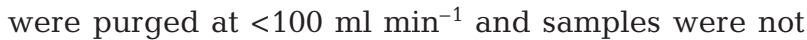
obtained until the conductivity, dissolved oxygen, temperature, and $\mathrm{pH}$ of the pumped groundwater stabilized (Puls \& Powell 1992, 1995). Limited volumes prevented the use of such precautions when sampling some intertidal piezometers and seepage chambers.

During spring and summer of 1997 and 1998, seawater samples from WNB were collected twice weekly to bi-weekly from a dock $50 \mathrm{~m}$ into the bay (Fig. 1) using acid-washed Teflon tubing which extended $4 \mathrm{~m}$ into prevailing winds and currents to a depth of $1 \mathrm{~m}$. Duplicate particulate organic carbon and nitrogen (POC and PON) and triplicate chlorophyll a samples were collected on precombusted GF/F glass-fiber filters (nominal pore size $=0.7 \mu \mathrm{m}$ ), and stored frozen. In 1998, chlorophyll a was size-fractionated using a $5 \mu \mathrm{m}$ Nitex $^{\odot}$ mesh. DOC, DON, nutrient and salinity samples (groundwater and water column) were filtered with acid-cleaned, polypropylene capsule filters $(0.2 \mu \mathrm{m}$; MSI Inc.) in the field, and immediately stored on ice. Within $2 \mathrm{~h}$, DOC samples were acidified with quartzdistilled nitric acid and frozen along with DON and nutrient samples.

Sample analyses. DOC samples were analyzed in duplicate by high-temperature catalytic oxidation using a Shimadzu TOC-5000 total organic carbon analyzer (Sugimura \& Suzuki 1988, Benner \& Strom 1993). Duplicate POC and PON samples were dried at $60^{\circ} \mathrm{C}$ before analysis on a Carlo Erba NA 1500 NCS system
(Sharp 1974). Total dissolved N (TDN) was analyzed in duplicate by persulfate oxidation techniques (Valderrama 1981) and DON was calculated by subtracting levels of nitrate, nitrite and ammonium from concentrations of TDN. Salinity was measured on a Beckman ${ }^{\circledR}$ induction salinometer (Model \# RS 7B). Chlorophyll a (chl a) was analyzed in triplicate by standard fluorometeric methods (Parsons et al. 1984). Within 2 wk of collection, nitrate (Jones 1984), urea (Newell et. al. 1967), nitrite, ammonium, phosphate and silicate (Parsons et al. 1984) were analyzed in duplicate by standard spectrophotometric methods using a 1 or $10 \mathrm{~cm}$ cell, depending on ambient concentrations. Measurements of J. Sharp's (University of Delaware) intercalibration DOC samples were within $5 \%$ of the consensus value. Measurements of NIST 16326 standard reference material for POC was within $8 \%$ of certified values. Recoveries of SPEX Certi-Prep ${ }^{\mathrm{INC}}$ dissolved organic nitrogen standard reference material was $101 \pm 9 \%$. Recoveries of SPEX Certi-Prep ${ }^{\mathrm{INC}}$ inorganic nutrient standard reference material were $104 \pm 5 \%$ for nitrate, $96 \pm 6 \%$ for ammonium and $103 \pm 5 \%$ for phosphate. Precombustion of glassware and GFF filters provided adequately low blanks for DOC, DON, and POC/PON (<10\% of lowest sample).

Hydraulic gradients and groundwater recharge. Three independent estimates of groundwater flow at WNB were calculated during this study: (1) a seasonal hydraulic gradient of the aquifer surrounding WNB; (2) a daily hydraulic gradient of the aquifer surrounding $\mathrm{WNB}_{\text {; }}(3)$ the recharge rate of aquifer surrounding WNB. Hydraulic gradients of groundwater surrounding WNB closely approximate groundwater flow rates entering WNB, since the two co-vary linearly in aquifers with homogenous sediments, such as WNB (Simmons 1986, Paulsen et al. 1998, Schubert 1998 1999). Hydraulic gradients $(G)$ were calculated by measuring water heights of 2 wells in a perpendicular line with WNB and employing the formula:

$$
G=\Delta h / \Delta l
$$

where $G$ is the hydraulic gradient, $\Delta h$ is the vertical difference in water height between the wells, and $\Delta l$ is the horizontal distance between the wells. A seasonal hydraulic gradient was calculated from December 1996 to September 19984 times annually (see Fig. 3), and a daily hydraulic gradient was calculated from June through September 1998 (see Fig. 3). Wells used for gradient measurements were located at the northeastern corner of WNB (Fig. 1), since $80 \%$ of the bay's groundwater recharge originates from this region (Paulsen et al. 1998). The volume of groundwater recharging into WNB was estimated using the methods of Steenhuis et al. (1985), who determined that seasonal changes in evapotranspiration is the process 
which most influences groundwater recharge on eastern Long Island. The watershed area $\left(3.0 \mathrm{~km}^{2}\right)$ for WNB was determined from USGS water table maps of Shelter Island's watershed (Schubert 1998). Mean daily recharge rates calculated with the Steenhuis et al. (1985) method $\left(7 \times 10^{6} \mathrm{ld}^{-1}\right)$ were similar to those previously calculated for WNB by independent methods $\left(6 \times 10^{6} \mathrm{l} \mathrm{d}^{-1}\right.$ : Schubert 1998). Precipitation data were obtained from the Northeast Regional Climate Center's Greenport Station (C. Veerland pers. comm.) and from the Southampton College Marine Station (B. Reimers pers. comm.).

Ancillary data. Aureococcus anophagefferens densities were determined on field samples fixed with glutaraldehyde ( $1 \%$ final concentration). Samples were enumerated by direct count methods employing a Zeiss Model D-7082 epifluorescent microscope and an immunofluorescent label as described by Anderson et al. (1989). Light penetration and the $1 \%$ light depth within the water column of WNB were calculated from Secchi disk readings. A multivariate regression model was created using $\mathrm{SAS}^{\odot}$ statistical software, Version 6.12. A. anophagefferens cell densities, and water quality data from 1995 in WNB were provided by the Suffolk County Department of Health Services, Office of Ecology (SCDHS 1995). On occasion, the amount of chlorophyll $a$ in WNB due to the presence of brown tide was estimated by assuming a constant chl a per cell value for $A$. anophagefferens $\left(0.035 \pm 0.003 \mathrm{pg} \mathrm{cell}^{-1}\right.$ for nutrient-replete cultures: Gobler 1995), and multiplying this value by the $A$. anophagefferens density. Although such calculations can be biased by variability of cellular chlorophyll content due to changes in light and nutrient regimes, such approximations have been used successfully in the past to compare A. anophagefferens biomass to that of the total algal community (Schaffner 1999, Gobler \& Sañudo-Wilhelmy 2001).

\section{RESULTS}

\section{Groundwater composition}

Groundwater surrounding WNB was enriched in several inorganic nutrients, and its composition changed as it seeped through intertidal sediments into the bay. Groundwater in the upper aquifer encompassing WNB (Wells A and D: Fig. 1) was partially oxygenated (dissolved oxygen, $\mathrm{DO},=318 \mu \mathrm{M})$, contained significant levels of nitrate (average of $257 \mu \mathrm{M}$ ), moderate levels of silicate and DOC (average of 35 and $32 \mu \mathrm{M}$ respectively) and low levels of ammonium, phosphate, and DON (average of $0.2,0.4$, and $2.0 \mu \mathrm{M}$ respectively: Fig. 2A). Samples collected from MHW piezometers, intertidal piezometers, and benthic seepage chambers
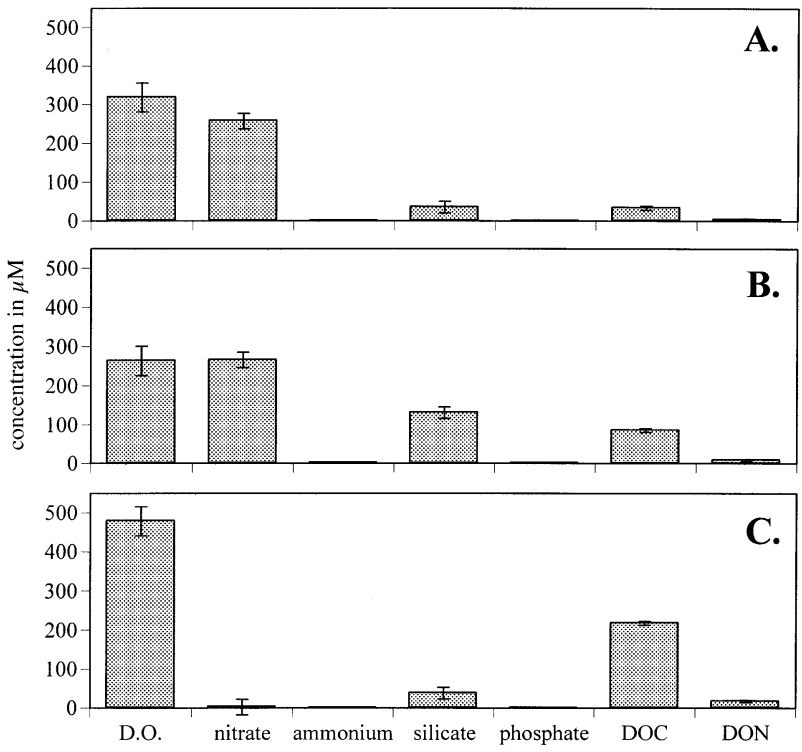

Fig. 2. Mean $( \pm 1 \mathrm{SD})$ concentrations of dissolved oxygen (DO), nitrate, ammonium, silicate, phosphate, DOC and DON in: (A) groundwater of the aquifer surrounding West Neck Bay (WNB) sampled from coastal wells June through October 1998 ( $\mathrm{n}=11$ ); (B) groundwater sampled from MHW piezometers, intertidal piezometers, and benthic seepage chambers June through October $1998(\mathrm{n}=15)$; and $(\mathrm{C})$ water column samples from WNB, $1997-1998(n=31)$

( $\mathrm{n}=18$; Sites B, C, E, F, and $1-4$ : Fig. 1) contained moderate levels of dissolved oxygen (average $=263 \mu \mathrm{M}$ ) and concentrations of inorganic and organic nutrients that were markedly higher than levels within inland wells (Fig. 2B). Specifically, concentrations of ammonium and DON were over 6 times higher $(1.2$ and $8 \mu \mathrm{M}$ respectively), and levels of DOC, silicate, and phosphate were roughly twice that of the inland aquifer $(102,80$ and $0.67 \mu \mathrm{M}$ respectively: Fig. $2 \mathrm{~A}, \mathrm{~B})$. In contrast, concentrations of nitrate seeping through the intertidal zone were nearly identical to levels in inland groundwater $(265 \mu \mathrm{M})$ (Fig. 2A,B). Compared to concentrations found in the water column of WNB (Fig. 2C), groundwater seeping into the bay was enriched in nitrate, silicate, ammonium, and phosphate, but had lower levels of DOC and DON (Fig. 2B,C). While levels of silicate, ammonium, and phosphate in groundwater seepage were approximately twice the levels found in WNB, nitrate levels were over 2 orders of magnitude higher (Fig. 2B,C). We observed no significant temporal variation in the levels of organic and inorganic nutrients in the groundwater surrounding (Sites A and D) or entering (Sites B, C, E, F) WNB from June to October 1998 (Gobler 1999). A 1999 study which found levels of nitrate, ammonium, silicate, phosphate and DOC at Sites A and D which were nearly identical to those we measured during 1998 


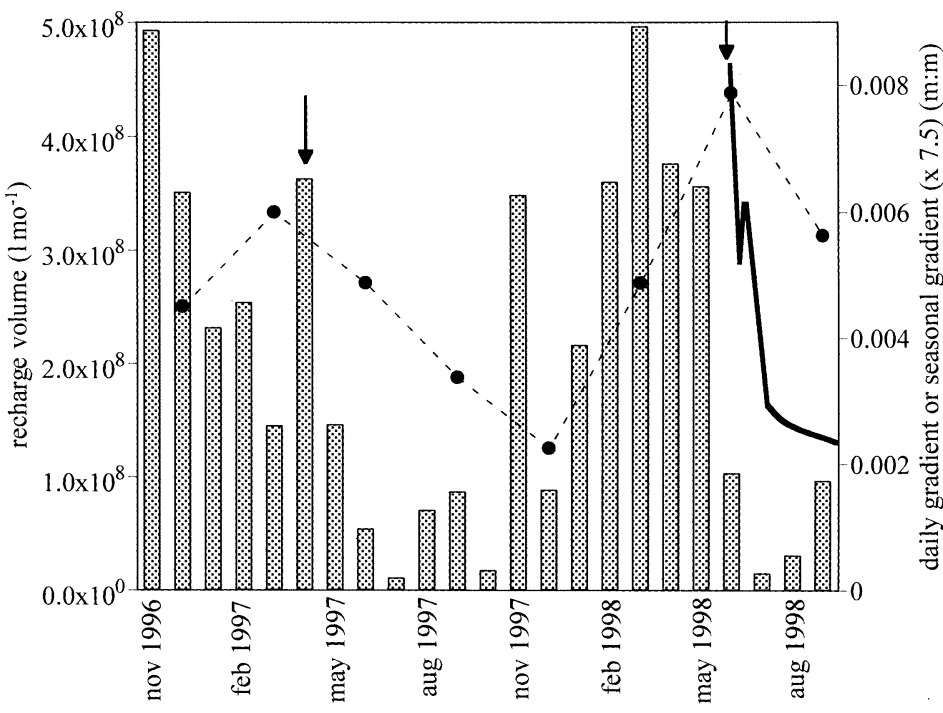

Fig. 3. Monthly groundwater recharge (bars), seasonal hydraulic gradient (--•--), and daily hydraulic gradient (black line) at WNB, 1996 to 1998. Arrows indicate dates of annual maximum in water column nitrate levels

(Rossi 2000) further suggests the absence of temporal variability in groundwater composition at WNB.

\section{Temporal variation of groundwater flow at WNB}

Hydraulic gradients and groundwater recharge calculations indicated notable differences between 1997 and 1998 groundwater flow at WNB (Fig. 3). While winter (November to February) recharge volumes were similar each year, a wet spring in 1998 resulted in $53 \%$ more recharge during March through May of $1998\left(1.23 \times 10^{9} 1\right)$ compared to the same period in 1997 $\left(6.52 \times 10^{8}\right.$ l: Fig. 3). Annual differences in groundwater recharge were reflected in the hydraulic gradients, as the 1998 seasonal gradient peak was 37\% larger and occurred later in the year than in 1997 (Fig. 3). Daily hydraulic gradient measurements, which began in early June 1998, exhibited a maximum which coincided with the seasonal gradient peak of 1998 (Fig. 3). During the hydraulic gradient maximum of each year (March and April 1997, late May and early June 1998) a substantial peak in nitrate was detected in WNB (arrowed in Fig. 3). During each year, these nitrate peaks were followed by a series of phytoplankton blooms, including a monospecific brown tide.

\section{Brown tide bloom dynamics}

In late April 1997, the highest nitrate levels $(1.1 \mu \mathrm{M})$ of the sampling period were observed in the water column of WNB, along with low chl $a$ and brown tide densities $\left(1.5 \mu \mathrm{g} \mathrm{l}^{-1}\right.$ and $1.0 \times 10^{3}$ cells $\mathrm{ml}^{-1}$ : Fig. 4A,B). By mid May (14 May), nitrate had decreased to $0.18 \mu \mathrm{M}$ and phytoplankton chl a had increased 5-fold to $7.25 \mathrm{\mu g} \mathrm{l}^{-1}$, marking the first phytoplankton bloom of the 1997 sampling year (Fig. 4A,B). By the end of May, this initial nonbrown tide bloom had dissipated, as chl a dropped to $2.2 \mathrm{\mu g} \mathrm{l}^{-1}$, and Aureococcus anophagefferens cells began to proliferate, existing at $1.0 \times 10^{4}$ cells $\mathrm{ml}^{-1}$ (Fig. 4B). In early June, the brown tide bloom at WNB reached peak densities of $4.95 \times 10^{5}$ cells $\mathrm{ml}^{-1}$ (Fig. 4B) and was monospecific, with $A$. anophagefferens representing nearly $100 \%$ of algal biomass (based on a chl a quota of $0.035 \pm 0.003 \mathrm{pg}$ cell $^{-1}$ : Gobler 1995, 1999). During the 1997 brown tide maximum, nitrate decreased (Fig. 4A). In contrast, levels of organic nutrients (DON, urea, DOC) remained relatively low and did not change substantially prior to, or during, the 1997 WNB bloom (Fig. 4C,D,E). By mid-June, the brown tide bloom began to dissipate as cell densities decreased to
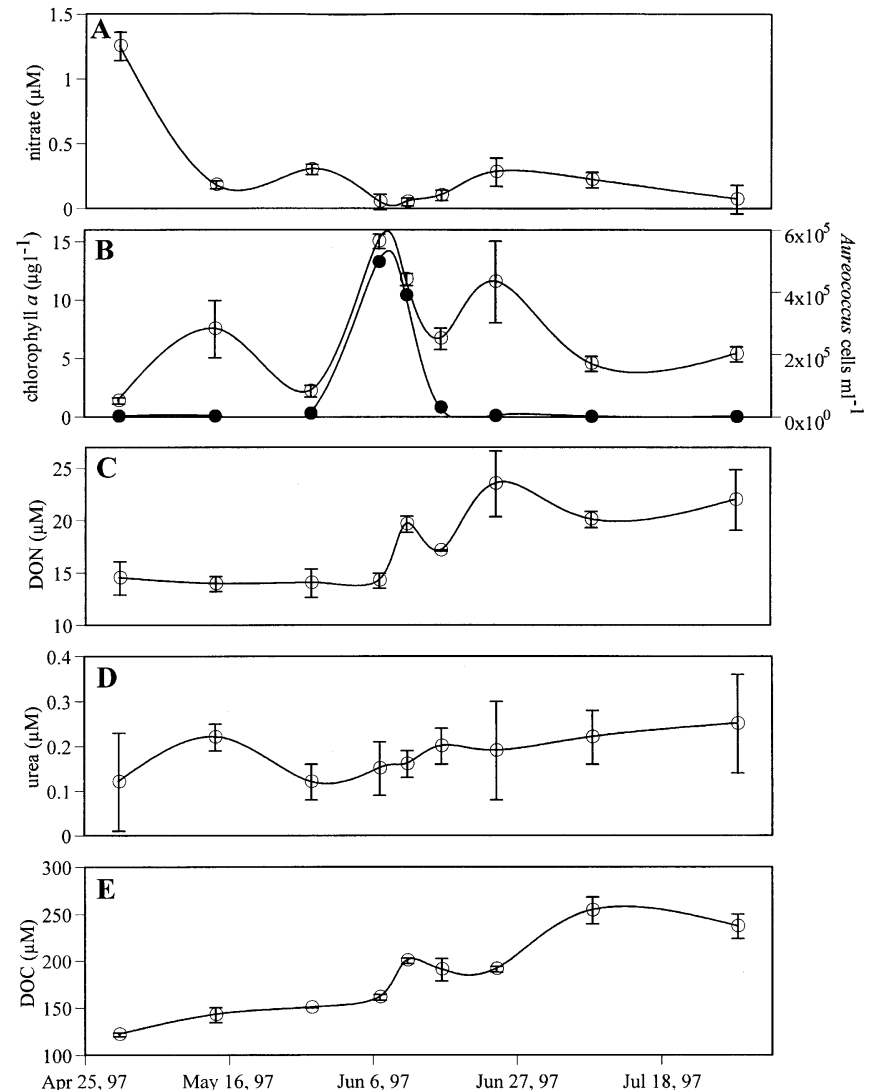

Fig. 4. Changes (means $\pm 1 \mathrm{SD}$ ) in (A) nitrate, (B) chlorophyll a (O) and Aureococcus anophagefferens cell density (•), (C) DON, (D) urea, and (E) DOC at WNB in 1997. June 1997 brown tide peak was preceded by elevated nitrate levels and a nonbrown tide chlorophyll bloom in April and May respectively 
$2.9 \times 10^{4}$ cells ml ${ }^{-1}$ on 16 June (Fig. 4B). Accompanying the demise of the bloom was a significant increase in levels of nitrate, DON, urea, and DOC (Fig. 4A, $, D, E$, E). By late June, $A$. anophagefferens densities were reduced to low levels $\left(<10^{2}\right.$ cells $\left.\mathrm{ml}^{-1}\right)$, where they remained for the rest of the sampling year.

In 1998, nitrate in WNB increased from low levels in April (monthly average $=0.13 \mu \mathrm{M}$ ) to relatively high levels ( 2 to $30 \mu \mathrm{M}$ ) during the late May/early June peak of groundwater flow (Figs $3 \& 5 \mathrm{~A}$ ). After this substantial nitrate input, a mixed-assemblage phytoplankton bloom developed, as chl a levels increased 6-fold from $5 \mathrm{\mu g} \mathrm{l}^{-1}$ on 26 May to $30 \mathrm{\mu g} \mathrm{l}^{-1}$ on 4 June (Fig. 5B). Size-fractionated chl a measurements along with light and epifluorescent microscopy indicated the dominance of autotrophic picoflagellates in this bloom ( $90 \%$ of chl $a<5 \mu \mathrm{m}$ : Gobler 1999). Organic nutrients in WNB increased substantially during the June chl a bloom, as the monthly average DON, urea and DOC levels were respectively 43,127 , and $27 \%$ higher than levels in late May (26 May: Fig. 5C,D,E). Aureococcus anophag-
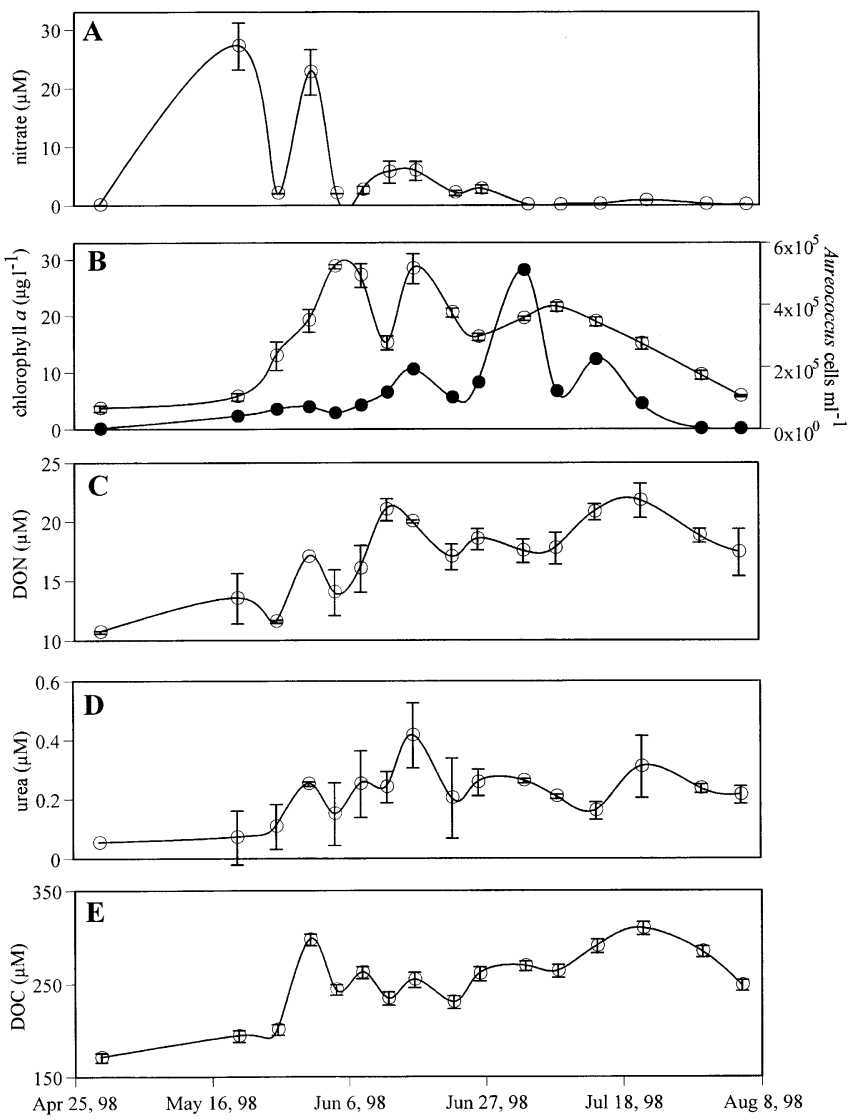

Fig. 5. Changes (means $\pm 1 \mathrm{SD}$ ) in (A) nitrate, (B) chlorophyll a (O) and Aureococcus anophagefferens cell density (•), (C) DON, (D) urea, and (E) DOC at WNB in 1998. July 1998 brown tide peak was preceded by elevated nitrate levels and a nonbrown tide chlorophyll bloom in May and June respectively efferens densities during the June chl a bloom steadily increased from $1.0 \times 10^{4} \mathrm{cells} \mathrm{ml}^{-1}$ in late May to $>1.0 \times$ $10^{5}$ cells ml $^{-1}$ in late June, representing 10 to $25 \%$ of the algal population (Fig. 5B; Gobler 1999). The brown tide became monospecific in WNB in early July, as $A$. anophagefferens grew to peak densities of $5.64 \times 10^{5}$ cells ml ${ }^{-1}$ and represented over $95 \%$ of the algal biomass (Fig. 5B; and Gobler 1999). During this bloom peak, the daily hydraulic gradient of groundwater at WNB was $50 \%$ lower than in early June (Fig. 3), and nitrate levels were low $(0.2 \mu \mathrm{M})$ for the first time since mid-May (Fig. 5A). DON decreased slightly $(0.5 \mu \mathrm{M})$ from levels found on 26 June during this bloom peak, while urea and DOC levels did not change significantly (Fig. 5C,D,E). Nitrate levels in WNB remained low for the remainder of July (Fig. 5A), while organic nutrients (DON and DOC) steadily increased through the month (Fig. 5C,E). In the 3 wk following the peak of the bloom, A. anophagefferens densities fluctuated between $2.5 \times 10^{5} \mathrm{cells} \mathrm{ml}^{-1}$ (14 July) and $0.8 \times 10^{5}$ cells $\mathrm{ml}^{-1}$ (21 July), representing 25 to $50 \%$ of algal biomass (Fig. 5B; and Gobler 1999). On 30 July, A. anophagefferens densities decreased to nearly zero, where they remained for the duration of the sampling year.

\section{DISCUSSION}

During this study, interannual differences in groundwater seepage into WNB were reflected in the magnitude and timing of both water column nitrate concentrations and phytoplankton biomass. In 1998, elevated levels of nitrate were measured in WNB during the annual peak in groundwater flow (Figs $3 \& 5 \mathrm{~A}$ ), and were followed by a mixed assemblage phytoplankton bloom that was succeeded by a brown tide (Fig. 5B). In 1997, a similar pattern was observed (Figs 3 \& 4), although the absolute peak in groundwater flow and water-column nitrate levels probably occurred prior to the initiation of our sampling campaign that year (see later subsection 'Groundwater flow and composition at $\mathrm{WNB}^{\prime}$ ). Compared to 1997, which was drier and experienced maximal groundwater flow in earlyspring (March and April: Fig. 3), 1998 was wetter, and experienced maximal groundwater flow in late-spring (late May and earlier June). Accordingly, levels of nitrate and chlorophyll in 1998 were substantially larger and increased later in the year compared to 1997 (Figs 4A,B \& 5A,B). While maximal Aureococcus anophagefferens densities were similar each year, the longer duration of the 1998 bloom (2 mo) compared to 1997 (3 wk), suggests that the magnitude of groundwater input may indirectly affect the duration of the brown tide, perhaps by impacting the duration and/or magnitude of pre-brown tide algal blooms. 


\section{Nitrogen and brown tide}

Over a decade of research has identified the capacity of Aureococcus anophagefferens to efficiently utilize organic compounds for nutrition (Dzurica et al. 1989, Berg et al. 1997, LaRoche et al. 1997). Phytoplankton blooms preceding brown tide could supply organic nutrients by means of cell leakage, grazing and/or benthic or pelagic microbial remineralization (Nagata \& Kirchman 1992, Bronk et al. 1994). In 1998, levels of urea, DON and DOC in WNB all increased significantly in the water column as A. anophagefferens densities increased during the June chl a bloom (Fig. 5C,D,E). This organically enriched environment may have provided the nutritional substrate which allowed this brown tide to bloom for over 2 mo (Fig. 5B-E).

In contrast to 1998, the 1997 WNB bloom occurred after a chl a bloom, but without any measurable increase of DON, urea, or DOC (Fig. 4C,D,E). However, there is evidence that the absence of a measurable organic $\mathrm{N}$ input may have limited the growth of the brief 1997 bloom (Table 1). The POC:PON ratios (mol:mol) found during the 1997 bloom peak (14.9) were the highest of our $2 \mathrm{yr}$ sampling campaign and greatly exceeded those exhibited by the 1998 bloom peak (9.31) (Table 1; and Gobler 1999). The absolute changes in POC and PON during these bloom peaks also suggest that the 1997 brown tide was $\mathrm{N}$-deficient. Increases in POC during 1997 bloom initiation $(84.2 \mu \mathrm{M}$ from 28 May 1997 to 7 June 1997: Table 1) were nearly equivalent to the amount expected from observed increases in cell density and published cellular $\mathrm{C}$ quotas for Aureococcus anophagefferens $\left(1.88 \times 10^{-13} \mathrm{~mol}\right.$ $\mathrm{C}_{\text {cell }}^{-1}$ [Gobler 1995] $\times 4.85 \times 10^{8}$ cells l$^{-1}=91.2 \mu \mathrm{M} \mathrm{C}$ : Table 1), suggesting that algal biomass accounts for nearly all the POC in WNB during blooms (Gobler 1999). However, the PON increase during the 1997 bloom peak (3.57 $\mu \mathrm{M} \mathrm{N}$ from 28 May to 7 June: Table 1) was less than a third of the quantity expected $(11.8 \mu \mathrm{M}$ based on $2.43 \times 10^{-14} \mathrm{~mol} \mathrm{~N}_{\text {cell }}^{-1}$ for N-replete cultures: Gobler 1995; and Table 1). This contrasts with the formation of the 1998 bloom maximum (from 26 June to 3 July) which showed increases in POC and
PON $(89.9 \mu \mathrm{M}$ C and $11.4 \mu \mathrm{M}$ N: Table 1$)$ that nearly balanced the amounts predicted $(79.9 \mu \mathrm{M} \mathrm{C}$ and $10.3 \mu \mathrm{M} \mathrm{N})$ from changes in cell densities $\left(4.25 \times 10^{8}\right.$ cells $\mathrm{l}^{-1}$ : Table 1 ). Furthermore, the $\mathrm{C}: \mathrm{N}$ of organic matter formed during 1997 bloom initiation (change in POC [84.2 $\mu \mathrm{M} \mathrm{C}$ ]:change in PON [3.57 $\mu \mathrm{M} \mathrm{N}$ ] from 28 May to 7 June), a measurement likely to be most representative of $A$. anophagefferens cells, was 23.6 (Table 1). This is significantly higher than the 1998 bloom peak value (7.89: Table 1), as well as published $\mathrm{C}: \mathrm{N}$ ratios for $\mathrm{N}$-replete cultures of this species $(7.0$ to 8.4: Gobler 1995, Gobler et al. 1997), and is a classic indicator of N-limitation (Goldman et al. 1979). If the absence of a DON input preceding the 1997 brown tide did lead to its N-limitation and ultimate demise, then perhaps organic $\mathrm{N}$ inputs are not required to initiate $A$. anophagefferens blooms as suggested by LaRoche et al. (1997), but are instead necessary to sustain them.
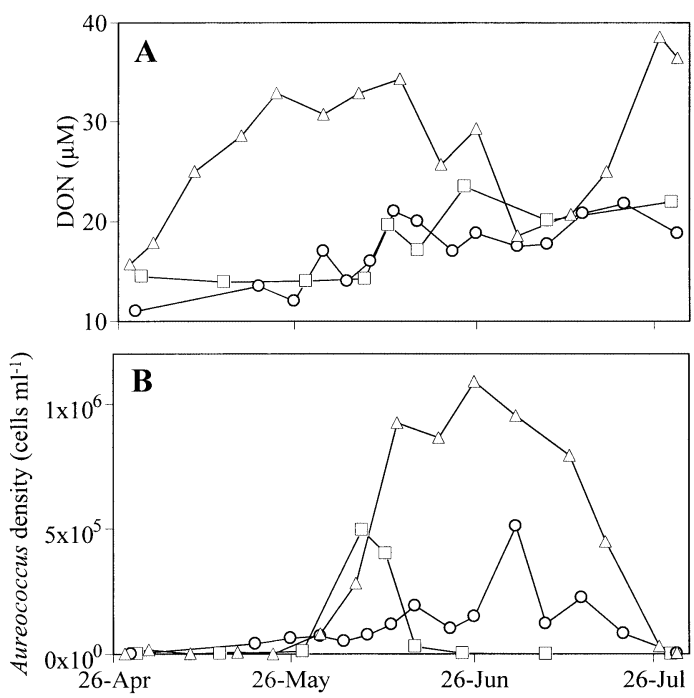

Fig. 6. (A) DON in WNB, April to July 1995 ( $\triangle$ : SCHDS 1995), 1997 (ם), and 1998 (O). (B) Aureococcus anophagefferens cell densities in WNB April to July of 1995 ( $\triangle$ : SCDHS 1995), 1997 (), and 1998 (०). Higher concentrations of DON in 1995 compared to 1997 and 1998 seemed to provide the substrate for a more intense brown tide bloom

Table 1. Mass balance of cellular C and N during peaks of the 1997 and 1998 Aureococcus anophagefferens blooms. POC and PON values are in $\mu \mathrm{M}$, POC:PON in mol:mol. Expected values are based on previously published cellular $\mathrm{C}$ and $\mathrm{N}$ quotas and ratios for nutrient-replete A. anophagefferens cultures (Gobler 1995, Gobler et al. 1997) and observed changes in cell density (Figs 4 \& 5) during each peak bloom-initiation period. C:N of initiated brown tide represents the change in POC and PON during the week of peak bloom initiation each year. Boldface denotes evidence of N-limitation during the 1997 brown tide bloom

\begin{tabular}{|lccccccc|}
\hline \multirow{2}{*}{ Bloom peak } & \multicolumn{2}{c}{ POC increase } & \multicolumn{2}{c}{ PON increase } & \multicolumn{2}{c|}{ Peak bloom POC:PON } & C:N of initiated \\
& Expected & Observed & Expected & Observed & Expected & Observed & brown tide \\
\hline 1997 (28 May-7 June) & $91.2 \pm 21.7$ & $84.2 \pm 2.50$ & $11.8 \pm 0.71$ & $\mathbf{3 . 5 7} \pm \mathbf{0 . 7 1}$ & $7.73 \pm 0.48$ & $\mathbf{1 4 . 9} \pm \mathbf{1 . 0 2}$ & $\mathbf{2 3 . 6} \pm \mathbf{0 . 9 9}$ \\
1998 (26 June-3 July) & $79.9 \pm 2.50$ & $89.9 \pm 6.67$ & $10.3 \pm 0.71$ & $11.4 \pm 2.14$ & $7.73 \pm 0.48$ & $9.31 \pm 2.37$ & $7.89 \pm 1.13$ \\
\hline
\end{tabular}


A comparison of temporal variability in DON during our study with levels measured during the 1995 WNB brown tide seems to confirm the necessity of organic $\mathrm{N}$ inputs for sustaining brown tide blooms (Fig. 6). In 1995, a WNB brown tide was preceded by DON levels significantly greater than those observed during 1997 and 1998, as concentrations more than doubled during May to $>30 \mu \mathrm{M}$ (Fig. 6A; and SCDHS 1995). This larger DON input seemed to provide the substrate to support a more intense Aureococcus anophagefferens bloom, as 1995 cell densities were sustained at levels 2-fold higher than those observed in 1997 and 1998 (Fig. 6B). Similar DON inputs were observed throughout the Peconic Estuary in May 1995, and were followed by the last estuary-wide brown tide event which lasted through the summer (SCDHS 1995). While increases in DON at WNB during 1997 and 1998 occurred after summer phytoplankton blooms (Figs 4C \& 5C), the May 1995 DON input occurred when chl a levels in WNB were abnormally low $\left(<3 \mu \mathrm{g} \mathrm{l}^{-1}\right.$ : SCDHS 1995), suggesting an alternate DON source in 1995. LaRoche et al. (1997) speculated that DON inputs to Long Island embayments were associated with benthic heterotrophic activity and hence would parallel bay temperature. However, there was no a significant difference in bay temperature between May $1995\left(16.4 \pm 2.3^{\circ} \mathrm{C}=\right.$ average $\pm \mathrm{SD})$, May $1997\left(15.6 \pm 2.1^{\circ} \mathrm{C}\right)$, and May 1998 $\left(17.7 \pm 3.0^{\circ} \mathrm{C}\right)$ in WNB (SCDHS 1995-1998). Since benthic algal communities are common to bays with large groundwater inputs (Johannes 1980, Sewell 1982) and the WNB water column was abnormally clear in spring of 1995 (Secchi disc depths to the bottom $(\sim 4 \mathrm{~m})$ versus average depth of $2.8 \mathrm{~m}$ during 1987 to 1994 and 1996 to 1998: SCDHS 1987-1998), it is possible that benthic algae were responsible for the observed DON input (MacIntyre et al. 1996, Cerco \& Seitzinger 1997). In a manner similar to pelagic species, a benthic algal community will probably leak DON as they grow or become 'shaded out' (Bronk et al. 1994, MacIntyre et al. 1996).

\section{Groundwater flow and composition at WNB}

The levels of nitrate in groundwater entering WNB are relatively high (>250 $\mu \mathrm{M}$ : Fig. $2 \mathrm{~B})$ compared to some other coastal areas in the Northeast US (Valiela \& Costa 1988, Giblin \& Gaines 1990) and on Long Island (Capone \& Bautista 1985, Montluçon \& Sañudo-Wilhelmy 2001). Mass balance calculations have determined that groundwater seepage accounts for $83 \%$ of WNB's DIN supply (Gobler 1999). Septic tanks and cesspools from the dense housing plots surrounding WNB $\left(<1 \mathrm{acre}^{-1}\right)$ are the likely source of nitrate in the groundwater, since there is no major agricultural activ- ity near the bay. Septic tanks contribute to high nitrate levels in many coastal environments (Persky 1986, Giblin \& Gaines 1990, Valiela et al. 1992), including Long Island (Leamond et al. 1992), by releasing ammonium which becomes nitrified as it moves through oxic water tables and sandy sediments towards embayments (Valiela et al. 1992). Low nitrate levels $(<7 \mu \mathrm{M})$ in groundwater beneath the undeveloped southeast corner of Shelter Island (Simmons 1986) further implicate anthropogenic enrichment of groundwater nitrate around WNB by septic tanks.

Diagenetic reactions within organic-rich sediments of estuaries produce copious amounts of organic (Burdige \& Homstead 1994, Burdige et al. 1995) and inorganic (Aller \& Benninger 1981, Fisher et al. 1982) nutrients. Therefore, the enrichment of ammonium, silicate, phosphate, DOC and DON in groundwater seeping into WNB through intertidal sediments (Fig. 2A,B) probably reflects the diagenetic degradation of organic matter at the sediment-water interface and the mixing of sediment porewater with groundwater. The observed modification of groundwater composition as it seeped into WNB suggests that inland monitoring wells may provide a poor proxy of the groundwater which permeates coastal embayments. Elevated levels of silicate found in groundwater surrounding and entering WNB (Fig. 2A,B,C) probably result from weathering and dissolution of sediments in the aquifer as the groundwater traverses flow paths (Hurley \& Armstrong 1985).

The flow of groundwater on Shelter Island is controlled by the hydraulic gradient of the aquifer, since the conductive properties of aquifer sediments on Shelter Island are homogenous (Simmons 1986, Schubert 1998, 1999). During this study we measured both seasonal and daily hydraulic gradients at WNB. While the seasonal gradient demonstrated general trends in groundwater flow to WNB (Fig. 3), the low frequency of measurements ( 4 times $\mathrm{yr}^{-1}$ ) was unlikely to indicate the precise time of annual peaks in groundwater flow. In contrast, high-resolution, daily gradient measurements revealed more detailed and dramatic changes in flow (Fig. 3). It is apparent that peak groundwater flow in 1998 occurred in late May and early June, since both the seasonal and daily hydraulic gradients peaked then, as did nitrate levels measured in WNB (Figs 3 \& 5A). Furthermore, groundwater recharge around WNB was elevated during the 4 mo prior to this gradient peak (Fig. 3), and recharge in the upper aquifer around WNB is known to precede discharge by a period of days to weeks (Paulsen et al. 1998). While the peak of the seasonal hydraulic gradient in 1997 was in March (Fig. 3), the highest groundwater discharge could have occurred any time within a month of this measurement. The highest water column nitrate 
during our 1997 campaign was measured on 29 April, representing what we believe was the end of the annual peak flow period at WNB. This hypothesis is supported by the recharge data. Since April 1997 had the highest monthly recharge volume of spring (Fig. 3), the seasonal gradient probably remained elevated during this month, accounting for the observed nitrate peak.

\section{Multivariate regression model of brown tide densities at WNB}

To understand which variables measured at WNB from 1997 to 1998 (Figs 2 to 5; and Gobler 1999) might best describe observed brown tide densities, a series of multivariate linear regression models were constructed. The most significant 5-parameter model uses nitrate and phosphate concentrations in WNB, the seasonal hydraulic gradient, the $1 \%$ light depth and nonbrown tide chlorophyll a levels in WNB: log (Aureococcus anophagefferens cells ml $\left.{ }^{-1}\right)=(5034 \times$ hydraulic gradient $)-(0.48 \times 1 \%$ light depth $[\mathrm{m}])-(3.78 \times$ phosphate $[\mu \mathrm{M}])-(0.05 \times$ nitrate $[\mu \mathrm{M}])-(0.05 \times$ non- $A$. anophagefferens chl a $\left.\left[\mu \mathrm{g} \mathrm{l}^{-1}\right]\right)+2.77$. This model accounts for $72 \%$ of the variability in brown tide densities during the 2 yr study period $\left(\mathrm{r}^{2}=0.72, \mathrm{p}<0.0001\right.$, $F=12.28, \mathrm{df}=31$ ). Of the 5 parameters in the model, hydraulic gradient, $1 \%$ light depth and phosphate are highly significant $(\mathrm{p}=0.0009,0.0047$ and 0.0001 respectively), whereas nitrate and non-brown tide chlorophyll $a$ are not individually significant $(p=0.25$ and 0.26 respectively). While it would have been preferable to employ a time-lagged model, since we have observed a sequence of events leading to brown tide at $\mathrm{WNB}$, unequal time periods between sample dates prevented such a statistical treatment of our data (Sokal \& Rolf 1981).

The significance of the hydraulic gradient in the model indicates that rather than repressing brown tide (LaRoche et al. 1997, Schubert 1998), high groundwater flow can promote blooms at WNB. Groundwater supplies nitrate to mixed-assemblage phytoplankton blooms which, when remineralized, can provide Aureococcus anophagefferens with recycled organic nutrients. It has been hypothesized that $A$. anophagefferens' ability to grow efficiently under low light levels contributes to the formation of dense brown tide (Milligan \& Cosper 1997), and the significant inverse correlation with the $1 \%$ light depth in our model supports this concept. A monospecific bloom would be solely responsible for severe light attenuation, and thus would make the $1 \%$ light depth an autocorrelating parameter with brown tide density. However, the brown tide was monospecific on only 3 of our 31 sample dates at WNB (Gobler 1999). Furthermore, we feel the low light levels during late May and June 1998 ( $\mathrm{n}=9$; Gobler 1999) contributed to the July monospecific bloom. Thus, water-column light penetration has a useful, and justified, predictive capability. Dissolved phosphate was inversely correlated with brown tide densities in our model. Since phosphate was enriched in groundwater seeping through intertidal sediments (Fig. 2A,B) and has been found to be correlated with bay temperatures in WNB (Gobler 1999), it is likely to be a proxy for sediment nutrient regeneration (Aller \& Benninger 1981, Fisher et al. 1982). It is possible that elevated phosphate levels could repress brown tide growth, as previously suspected by Cosper et al. (1989). However, we feel that the significant inverse correlation with phosphate and $A$. anophagefferens densities may indicate that the 1997 and 1998 blooms were not fueled by diffusive benthic fluxes, but instead were stimulated by nutrients directly (nitrate) and indirectly (remineralized DON) associated with groundwater inputs.

\section{Conclusions}

During this study we observed the proliferation of brown tide at WNB after periods of high groundwater flow rates (1997 and 1998) and high nitrate levels (1998). Such observations seem contradictory to current hypotheses regarding Aureococcus anophagefferens bloom initiation which suggest that brown tide occur only during years of low groundwater flow and nitrate levels (LaRoche et al. 1997, Schubert 1998). We propose the following explanation to account for the

\section{(A) Pre brown tide bloom}

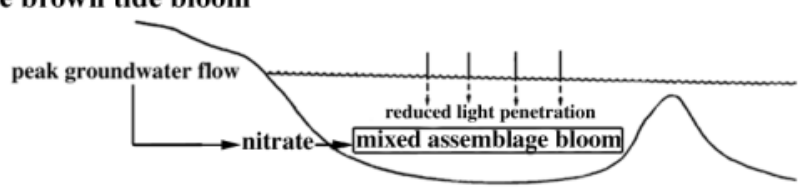

(B) Monospecific brown tide

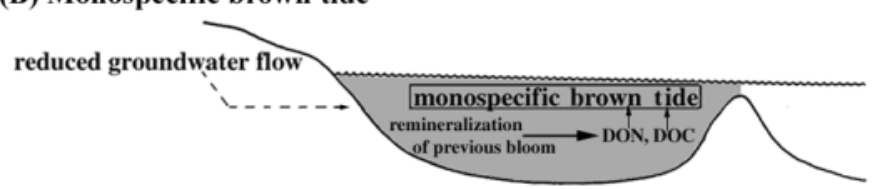

Fig. 7. Conceptualized diagram of the temporal progression of groundwater flow and brown tide blooms in WNB during 1997 and 1998. (A) During peak groundwater flow periods, mixed-assemblage phytoplankton blooms develop; (B) the brown tide becomes monospecific as groundwater flow and light levels are reduced, initial non-brown tide algal blooms are remineralized, and concentrations of DON and DOC become elevated 
occurrence of brown tide blooms at WNB in 1997 and 1998 (Fig. 7). Since A. anophagefferens has nitrate uptake capabilities similar to those of most phytoplankton (Szmyr et al. 1998), it is able to grow as part of a normal algal assemblage during periods of elevated groundwater flow and nitrate supply, as in June 1998 (Fig. 7). Reduced light penetration during dense mixed blooms gives A. anophagefferens a competitive advantage over algal species poorly adapted to low light regimes (Milligan \& Cosper 1997; this study: Fig. 7). When groundwater seepage rates diminish, a niche is created for a monospecific brown tide bloom. Unlike many other coastal algal species, $A$. anophagefferens has the ability to switch from DIN utilization to heterotrophic growth on DON (Dzurica et al. 1989, Berg et al. 1997). Since organic N (and C) becomes abundant following peaks in algal density, the postpeak groundwater flow period seems to create a scenario conducive for uni-algal brown tide blooms (Fig. 7). Previous hypotheses regarding brown tide and groundwater flow have relied on the mean height of groundwater in coastal wells during June through May of a given 12 mo period to predict blooms the following summer (LaRoche et al. 1997, Schubert 1998). Since it is the transition from high to low groundwater flow in late spring that seems to create ideal bloom conditions, we suggest that short-term (weeks to months) temporal variation in groundwater seepage may better forecast the occurrence of brown tide in WNB, and perhaps in other embayments on Long Island.

Acknowledgements. We are grateful for helpful comments on this manuscript from R. Aller, N. Fisher, R. Flegal, C. Lee, and 3 anonymous reviewers. We thank R. Paulsen for installation of monitoring wells and seasonal hydraulic gradient information and D. O'Rourke and T.-F. Wong for daily hydraulic gradient information. We thank K. Black for access to WNB and K. Henderson for assistance with statistical analysis. We thank R. Nuzzi and R. Waters for SCDHS data. C.J.G. thanks Dr R. H. Berry for informative hydrological discussions. This research was supported by NOAA's Coastal Ocean Programs award NA66 RG0368 for New York Sea Grant Institute.

\section{LITERATURE CITED}

Aller RC, Benninger LK (1981) Spatial and temporal patterns of dissolved ammonium, manganese, and silica fluxes from bottom sediments of Long Island Sound, USA. J Mar Res 39:295-314

Anderson DM, Kulis DM, Cosper EM (1989) Immunofluorescent detection of the 'brown tide' organism, Aureococcus anophagefferens. Lect Notes Coast Estuar Stud 35: 213-228

Benner R, Strom M (1993) A critical evaluation of the analytical blank associated with DOC measurements by hightemperature catalytic oxidation. Mar Chem 41:153-160

Berg GM, Gilbert PM, Lomas MW, Burford M (1997) Organic nitrogen uptake by the chrysophyte Aureococcus anopha- gefferens during a brown tide bloom event. Mar Biol 129: 377-387

Bricelj VM, Lonsdale DL (1997) Aureococcus anophagefferens: causes and ecological consequences of brown tide in US mid-Atlantic coastal waters. Limnol Oceanogr 42: 1023-1038

Bronk DA, Glibert PM, Ward BB (1994) Nitrogen uptake, dissolved organic nitrogen release, and new production. Science 265:1843-1845

Burdige DJ, Homstead J (1994) Fluxes of dissolved organic carbon from Chesapeake Bay sediments. Geochim Cosmochim Acta 58:3407-3424

Burdige DJ, Huag CM, Krishna N, Scully FE (1995) Aliphatic amines in Chesapeake Bay sediments. Mar Chem 51:45-54

Capone DG, Bautista MF (1985) A groundwater source of nitrate in nearshore marine sediments. Nature 313:214-216

Cerco CF, Seitzinger SP (1997) Measured and modeled effects of benthic algae on eutrophication in Indian RiverRehoboth, Delaware. Estuaries 20:231-248

Cosper EM, Dennison WC, Milligan AJ, Carpenter EJ, Lee C, Holzapfel J, Milanese L (1989) An examination of the environmental factors important to initiating and sustaining 'brown tide' blooms. Lect Notes Coast Estuar Stud 35: $317-340$

Dilorenzo JL, Ram RV (1991) Flushing-time estimates for West Neck Harbor: a small tidal embayment of the Peconic Bays, New York. Final report to the Suffolk County (NY) Department of Health Services (SCDHS), Office of Ecology. SCDHS, Office of Ecology, Riverhead

Dzurica S, Lee C, Cosper EM, Carpenter EJ (1989) Role of environmental variables, specifically organic compounds and micronutrients, in the growth of Chrysophyte Aureococcus anophagefferens, the 'brown tide' microalga. Lect Notes Coast Estuar Stud 35:229-252

Fisher TR, Carlson PR, Barber RT (1982) Sediment nutrient regeneration in three North Carolina estuaries. Estuar Coast Shelf Sci 14:101-116

Giblin AE, Gaines AG (1990) Nitrogen inputs to a marine embayment: the importance of groundwater. Biogeochemistry 10:309-328

Gobler CJ (1995) The role of iron in the occurrence of Aureococcus anophagefferens blooms. MS thesis, State University of New York, Stony Brook

Gobler CJ (1999) A biogeochemical investigation of Aureococcus anophagefferens blooms: interactions with organic nutrients and trace metals. PhD dissertation, State University of New York, Stony Brook

Gobler CJ, Sañudo-Wilhelmy SA (2001) Effects of organic carbon, organic nitrogen, inorganic nutrients, and iron additions on the growth of phytoplankton and bacteria during a brown tide bloom. Mar Ecol Prog Ser 209:19-34

Gobler CJ, Hutchins DA, Fisher NS, Cosper EM, Sañudo-Wilhelmy SA (1997) Release and bioavailability of C, N, P, Fe, and Se following viral lysis of a marine chrysophyte. Limnol Oceanogr 42:1492-1504

Goldman JC, McCarthy JJ, Peavey DG (1979) Growth rate influences on the chemical content of phytoplankton in oceanic waters. Nature 279:210-214

Hurley JP, Armstrong DE (1985) Ground water as a silica source for diatom production in a precipitation-dominated lake. Science 227:1576-1578

Johannes RE (1980) The ecological significance of submarine discharge of groundwater. Mar Ecol Prog Ser 3:365-373

Jones MN (1984) Nitrate reduction by shaking with cadmium: alternative to cadmium columns. Water Res 18:643-646

Keller AA, Rice RL (1989) Effects of nutrient enrichment on natural populations of the brown tide phytoplankton Aure- 
ococcus anophagefferens (Chrysophyceae). J Phycol 25: 636-646

Kinney EH, Roman CT (1998) The response of primary producers to nutrient enrichment in a shallow estuary. Mar Ecol Prog Ser 162:89-98

LaRoche J, Nuzzi R, Waters R, Wyman K, Falkowski PG, Wallace DWR (1997) Brown tide blooms in Long Island's coastal waters linked to variability in groundwater flow. Glob Change Biol 3:397-410

Leamond CE, Haefner RJ, Cauller SJ, Stackelberg PE (1992) Ground-water quality in five areas of differing land use in Nassau and Suffolk counties, Long Island New York. US Geological Survey, Wash (Open-File Report No. 91-180)

Lonsdale DJ, Cosper EM, Kim WS, Doall MH, Divadeenam A, Jonasdottir SH (1996) Food web interactions in the plankton of Long Island bays, with preliminary observations on brown tide effects. Mar Ecol Prog Ser 134:247-263

MacIntyre HL, Geider RJ, Miller DC (1996) Microphytobenthos: the ecological role of the 'secret garden' of unvegetated, shallow-water marine habitats. 1. Distribution, abundance, and primary production. Estuaries 19:186-201

Milligan AJ, Cosper EM (1997) Growth and photosynthesis of the 'brown tide' microalga Aureococcus anophagefferens in subsaturating constant and fluctuating irradiance. Mar Ecol Prog Ser 153:67-75

Montluçon D, Sañudo-Wilhelmy SA (2001) Influence of groundwater seepage on nutrient and metal concentrations in a coastal environment: Flanders Bay, Long Island, NY. Environ Sci Technol 35:480-486

Nagata T, Kirchman DL (1992) Release of macromolecular organic complexes by heterotrophic marine flagellates. Mar Ecol Prog Ser 83:233-246

Newell BS, Morgan B, Cundy J (1967) The determination of urea in seawater. J Mar Res 25:201-202

Nixon SW, Pilson MEQ (1983) Nitrogen in estuarine and coastal marine Ecosystems. In: Carpenter EJ, Capone DG (eds), Nitrogen in the marine environment. Academic, Press Inc, New York, p 411-458

Parsons TR, Maita Y, Lalli CM (1984) A manual of chemical and biological methods for seawater analysis. Pergamon Press Ltd, Oxford

Paulsen RJ, Smith CF, Wong TF (1998) Defining freshwater outcrops in West Neck Bay, Shelter Island, New York, using direct contact resistivity measurements and transient underflow measurements. In: Hansen G (ed) Geology of Long Island and Metropolitan New York, Proceedings from the Meeting of the Long Island Geologists, 17 April 1997. SUNY Press, Stony Brook, p 421-427

Persky JH (1986) The relation of groundwater quality to housing density, Cape Cod Massachusetts. Water Resour Investig Rep US Geol Surv 86-4093

Puls RW, Paul CJ (1995) Low-flow purging and sampling of ground water monitoring wells with dedicated systems. Ground Water Monit Rev 15:116-123

Puls RW, Powell RM (1992) Acquisition of representative groundwater quality samples for metals. Ground Water Monit Rev 12:167-176

Rossi FK (2000) Size-fractionated trace metals, organic carbon, and inorganic nutrients in groundwater: importance of colloidal forms. MS thesis, State University of New

Editorial responsibility: Otto Kinne (Editor),

Oldendorf/Luhe, Germany
York, Stony Brook

Schaffner R (1999) The role of suspension feeding bivalves in the initiation and control of Aureococcus anophagefferens blooms. Masters thesis, State University of New York, Stony Brook

Schubert CE (1998) Areas contributing ground water to the Peconic Estuary, and ground-water budgets for the North and South Forks and Shelter Island, Eastern Suffolk County, New York. Water Resour Investig Rep US Geol Surv $97-4136$

Schubert CE (1999) Ground-water flow paths and travel time to three small embayments within the Peconic Estuary, Eastern Suffolk County, New York. Water Resour Investig Rep US Geol Surv 98-4181

Sewell PL (1982) Urban groundwater as a possible nutrient source for an estuarine benthic algal bloom. Estuar Coast Shelf Sci 15:569-576

Sharp JH (1974) Improved analysis for particulate organic carbon and nitrogen in seawater. Limnol Oceanogr 19: 984-989

Short FT, Burdick DM (1996) Quantifying eelgrass habitat loss in relation to housing development and nitrogen loading in Waquoit Bay, Massachusetts. Estuaries 19:730-739

Simmons DL (1986) Geohydrology and ground-water quality on Shelter Island, Suffolk County, New York, 1983-1984. US Geological Survey Water Resources Investigations 85-4165

Sokal RR, Rolhf FJ (1981) Biometry. The principles and practice of statistics in biological research, 2nd edn. WH Freeman \& Co, New York

Staver KW, Brinsfield RB (1996) Seepage of groundwater nitrate from a riparian agrosystem into the Wye River Estuary. Estuaries 19:359-370

Steenhuis TS, Jackson CD, Kung SKG, Brutsaert WH (1985) Measurement of groundwater recharge on Eastern Long Island, NY, USA. J Hydrol (Amst) 79:145-169

Suffolk County (NY) Department of Health Services (SCDHS) (1987-1998) Annual reports of water quality in the Peconic Estuary. SCDHS, Office of Ecology, Riverhead, New York

Sugimura Y, Suzuki Y (1988) A high temperature catalytic oxidation method for the determination of non-volatile dissolved organic carbon in seawater by direct injection of a liquid sample. Mar Chem 24:105-131

Szmyr DB, Alexander JE, Boyer GL (1998) Characterization of nitrate reductase from the brown tide alga, Aureococcus anophagefferens. EOS Trans Am Geophys Un 79:87

Valderrama JC (1981) The simultaneous analysis of total nitrogen and phosphorus in natural waters. Mar Chem 10: 109-122

Valiela I, Costa J (1988) Eutrophication of Buttermilk Bay, a Cape Cod coastal embayment: concentrations of nutrients and watershed nutrient budgets. Environ Manag 12: $539-551$

Valiela I and 11 others (1992) Coupling of watersheds and coastal waters: sources and consequences of nutrient enrichment in Waaquoit Bay, Massachusetts. Estuaries 15: 443-457

Vieira MEC (1989) The case for meteorologically driven fluctuations in residence times of Long Island waters subject to algal bloom. Lect Notes Coast Estuar Stud 35:295-306

Submitted: April 28, 2000; Accepted: October 26, 2000

Proofs received from author(s): July 3, 2001 